\title{
Model of Socialization and Internalization of State Defense Values Among UPN "Veteran" Yogyakarta Students to Embody "State Defense Campus"
}

\author{
Isbandi Sutrisno ${ }^{1}$, Sigit Tripambudi ${ }^{2}$ \\ ${ }^{1}$ Communication Science Dept on UPN "Veteran" Yogyakarta, Indonesia \\ ${ }^{2}$ Communication Science Dept on UPN "Veteran" Yogyakarta, Indonesia \\ Corresponding Author's Email: mrsgt_upnyk@yahoo.com
}

\begin{abstract}
The issue of state defense becomes an important issue as the emerge of the descent of nationalism, the fading spirit of unity, economic domination by foreigners issues and so on. National Development University "Veteran" of Yogyakarta (UPNVY) is the college which has concern for the state defense problem. It reinforced by Presidential Regulation No. 121 of 2014 concerning the Establishment of National Development University "Veteran" of Yogyakarta, which is necessary to develop as a State Defense Campus. UPNVY campus wants to produce quality graduates who have the state defense values so that they have the spirit to apply the capacity they have for the nation and state. Therefore, the formulation of the socialization and internalization of state defending values model to students was formulated. This model is carried out through an integrated process under the coordination of the Kampus Bela Negara, since the student enters until the student completes their studies. Five courses in the pillars of state defense (Wimaya, Pancasila, Citizenship. Religion and Sport) and all courses provide the content for state defense. The process is strengthened by examplary in discipline, struggle and creativity. The symbols of state defense are also presented to create a state defense atmosphere. The supporting factors to realize UPNVY as a state defense campus is a historical factor, which stated that UPNVY was established to facilitate the national movement fighters in the independence period to study. The spirit of the struggle to defend the country continues to be maintained and become a maintained value.
\end{abstract}

Keywords: state defense, socialization, internalization

\section{INTRODUCTION}

The problem of state defense arises when it is associated with issues surrounding the decline of nationalism in Indonesia. The indications are such as the problem of lack of economic freedom over foreign domination, lack of love for national products, declining national values, many cases of corruption to 
delinquency/damage among youth/students. These problems must not be underestimated. The accumulation of the problem can gradually put the country into a state of bankruptcy, and it can even put Indonesia in a state co-opted by foreign powers.

National Development University "Veteran" of Yogyakarta (UPNVY) is a college that has concern for the state defense matter. This is reinforced by Presidential Regulation No. 121 of 2014 concerning the Establishment of National Development University "Veteran" of Yogyakarta. It is necessary to develop the National Development University "Veteran" of Yogyakarta as a State Defense Campus. This is in the context of facing threats to state sovereignty in the form of non-military threats which include internet crime, corruption, drugs, terrorism, radicalism, and the replacement of state ideology. National Development University "Veteran" of Yogyakarta plays an active role in deterrence in the form of smart power and can be a candradimuka crater for intellectual candidates, qualified next generation, and nation leaders who are able to become pioneers of development based on the spirit of state defense in the global era.

State Defense National Defense is the attitude and behavior of citizens who are organized in a comprehensive, integrated and continuous manner based on a love for the motherland, national and state awareness and belief in Pancasila as the state ideology, in order to face threats from both outside and within the country, which endanger and threaten sovereignty both in the fields of ideology, politics, economics, social, culture, and defense and security. It is hoped that UPNVY will be able to produce graduates of the State Defender Intellectual Cadres, and be able to become development pioneers. UPNVY is also expected to improve the quality of graduates who have global competitiveness and have the spirit of state defense through quality learning that is packaged in education and teaching, research and community service.

The results of research conducted by previous researchers regarding the meaning of state defense values for UPNVY students showed that: (a) UPNVY state defense campus students initially interpreted the state defense identical to compulsory military service. But their understanding changed after being straightened out and interpreted the state defense in the broadest sense, namely maximizing all potential possessed for the nation and state of Indonesia's benefit (b) UPNVY state defense campus students interpret national defense as very important for students, but the internalization process designed through state defense courses has not been maximized. Interaction of state defense symbols is still far less compared to other more popular symbol interactions. (c) UPNVY state defense campus students have resistance to the means state defense values because they see the lack of facilities, infrastructure and services. This is contrary to the spirit of state defense values.

The results of the study indicate that the state defense campus label has not been able to internalize the state defense values among UPNVY students. The scenarios process through a series of academic and non-academic activities have not been able to meet the desired expectations. Through this series of follow-up 
studies, it is expected to find a series of socialization and internalization process formula of state defense values for UPNVY students.

This research is very appropriate as one form of evaluation and provides a solution to instill the state defense values among UPNVY students, bearing in mind that UPNVY has declared itself a state defense campus. Of course, various parties have their own hopes for the capacity of UPNVY as a national defense campus, especially in terms of the learning process and the capacity of its graduates. This is a challenge that must be proven. This research will formulate a model of socialization and internalization of state defense values among UPN "Veteran" Yogyakarta students to embody the "State Defense Campus". The formulation will begin by identifying the supporting and inhibiting factors in the socialization and internalization of state defense values among UPN "Veteran" Yogyakarta students "State Defense Campus".

\section{LITERATURE REVIEW}

\section{Theory of Message Production}

Socialization and internalization is a communication process. Hovlan (1948) defines communication as the process by which an individual (communicator) conveys a message (verbal symbol) to change the behavior of other individuals. Thus in the process of communication, socialization and internalization requires the role of an aggressive and creative communicator in formulating messages. Little John (1996) explains the theory of message production relating to communicators. One theory is called the Rhetorical Sensitivity Theory. This theory explains that communicators tend to adjust messages with the audience as the beginning of effective communication. There are 3 types of communicators, namely:

a. Noble selves (rigid)

b. Rhetorical reflector (merge with the audience)

c. Rhetorical sensivity (moderat) by paying attention to yourself, the situation and other people.

Another message production theory is called the Communication style theory. This theory explains that communication occurs on 2 levels, not only providing information but also presenting information. The style of delivering a message can be before-after- or when the main message is delivered. There are 9 communication styles:
a. Dominance
f. Impresion
b. Dramatic behavior
g. Leaving
c. Openness
i. Relaxation
d. Contentiousness
j. Friendliness
e. Animation

The choice of communication style becomes important if it is related to the type of message that will be delivered, the target audience and the desired impact. An intelligent communicator will learn the conditionals that occur before choosing 
a communication style. Many communication failures occur due to mismatch between the choice of contextual communication styles of communication events.

\section{Learning Theory}

The learning process is a complex process that involves many components that influence each other. In addition to the instructor component (communicator), messages (learning materials) and communicants (learners); it must also be understood concepts and theories of learning to achieve maximum learning outcomes. Learning theories and concepts will lead to appropriate learning approaches in accordance with the conditional learning that will be practiced.

Albert Bandura in his Social Learning Theory, (in Synder and J Lopez, 2007: 179-180) states that behavior can be changed through the learning process. Bandura perfects social learning theory by adding behavioral and cognitive aspects. Behavioral learning means the environment causes a person to perform certain behaviors. Cognitive learning means that psychological factors also play a role in influencing how a person behaves. Humans can imitate behavior, but they also have the ability to choose and sort out the behavior they want to learn. The ability to sort and choose is the cognitive aspect intended.

Humans learn by observing others. The fact is that human knowledge is obtained from other humans. In other words, what humans know is based on the explanations given by other humans. This process continues throughout human life. In understanding things, according to human social learning theory uses: expectations, observational, behavioral capabilities, self-efficacy, reciprocal determinism and reinforcement.

Hope or expectations are the main concepts in social learning theory. Human knowledge must be able to realize the expectations of the environment and beliefs in something must be in accordance with the beliefs of the environment. Observational learning means that an individual bases their knowledge by observing others in the environment. An individual will recognize the behavior of others, adjust to himself, and then mimic the behavior in society. Everything they know comes from the behavior of the people around them. Behavioral capacity refers to the fact that a person's knowledge is needed to influence his behavior. While other people's behavior might influence you, your behavior will not be affected until you know/realize. Only when you realize it, you can change your behavior to be accepted by the public. Self-efficacy is one's belief in oneself. If someone believes in his knowledge, he will act on his knowledge. He will act if he is confident with his actions. Reciprocal determinism is that people copy behavior when they interact. When someone is in one environment, he will adapt to that environment. Reinforcement is a response from others that can strengthen or weaken a behavior. Therefore Bandura calls humans are active processors. Humans are not just imitating, but they also think about the consequences of the behavior to be imitated. If a behavior does not provide benefits for himself then it will not be done and vice versa.

According to Albert Bandura, in the process of learning every response made by someone is always followed by a number of consequences. Some are 
satisfying, some are unsatisfactory and some are ignored. Bandura believes that complex behaviors can be learned when humans think and evaluate the consequences of these behaviors (Feis and Feis, 2008: 410-411).

The consequences of response have three functions. First, the consequences of response inform the effects of the action. This can be a guide for future action. Second, the consequences of responses motivate anticipatory behavior; it means that we can symbolically represent future behavioral outputs and act on it. Humans not only have the ability to understand, but are also able to predict. Third, the consequences of responses strengthen behavior. Bandura believes that although reinforcement is often not realized and works automatically, cognitive intervention can also influence complex patterns of behavior. He believes that learning is far more efficient when learners are cognitively involved in learning situations and understand which behaviors can produce appropriate responses.

Bandura believes that new behavior can be achieved through two main types of learning: learning by observing and learning by doing. The core element of learning by observing is modeling, which includes observation of the correct activities, correctly encoding these events to be represented in memory, performing actual behavioral performance and providing sufficient motivation. Action learning allows one to achieve complex patterns of behavior through direct experience by thinking about and evaluating the consequences of that behavior.

The learning process allows humans to have certain degrees in controlling the events that shape the direction of their lives. However, this control is in the reproxical interaction between three personality dimensions namely personality, behavior and environment variables. According to Skinner, behavior is a function of the environment. That means, the behavior can ultimately be traced to nonpersonal forces. If the environment changes, the behavior also changes. But what changes the environment? Human behavior can also train counter-control to the environment although in his final analysis Skinner remains convinced that countercontrol behavior is determined by other environments.

Skinner (1953) in Feis and Feis (2008: 383-385) mentions two types of learning conditioning, namely classical and operant conditioning. In classical conditioning (respondents) a response is expected to arise from organism through a specific stimulus that is known. While in operant conditioning (Skinnerian) a behavior that is expected to arise after getting reinforced.

The main difference between classical and operant conditioning is: in classical conditioning behavior arises from organisms, whereas in operant conditioning, behavior is transmitted. The response that is raised is pulled out from within the organism, while the response emitted is the response that just appears. Therefore the response is not in the organism so it cannot be pulled out; then Skinner prefers the term "emitted". The emitted response is a response that never existed before in an organism other than just popping out because of the history of organismic strengthening of the individual or the evolutionary history of the species itself.

In classical conditioning a neutral stimulus (which is conditioned) is paired with an unconditioned stimulus - the stimulus before conditioning - several times 
until it is able to issue such an unconditioned response as before. For example reflexes (phobias, anxiety).

Whereas in operant conditioning, the key is the immediate strengthening of the response. The organism does something first, then enhances the environment. Strengthening in turn increases the likelihood that the same behavior will reappear. This conditioning is called operant conditioning because organisms operate in the environment to produce a special effect. Operant conditioning changes the frequency of a response or the possibility for a response to occur. Strengthening does not cause behavior but it does prepare the atmosphere for repetition.

Another approach is the behaviorist approach pioneered by Watson. This approach has several important theoretical parts. First Sarbon Theory (stimulus and response bond theory). According to this theory complex behavior can be analyzed into a series of stimulus and response "units" called reflexes. Second, observation and impression (sensation and perception) which focuses on motor responses from hearing, vision and so on. Third, affective feelings and behavior. Happy and unhappy is a senso-motoric matter to find out the emotional reactions that are carried from birth. Emotional reactions can be grown by conditioning and conditional emotional reactions can be eliminated by reconditioning. Fourth, theories about thinking. Thinking is senso-motoric behavior, including thinking to yourself. Fifth, the influence of the environment (education, learning, experience) to individual development. There is very little natural reaction from birth. Habits are formed in development, because of training and learning (Suryabrata Sumadi, 1990: 286-291).

Another theory is the Gestalt theory which says that learning is essentially the most important is the first adjustment, which is getting the right response. This is because finding the right response depends on "sruckturierung" rather than the material available in front of the student, so the ease or difficulty of the problem is primarily a matter of observation. In a certain sense if faced with the problem of observation and if you can see the situation correctly it will be able to get enlightenment and can solve the problem at hand. The assumption is that the laws or principles that apply to the observation process can be transferred to students, so to understand the learning process it is necessary to understand the laws that govern the observation process.

The laws of observation according to Gestalt theory. According to this theory there is one main law namely pragnanz law (content/coverage) and four additional laws (subsiders) which are subject to the main law; namely the laws of closeness, closure, equality and continuity. The law of pragnanz shows the direction of all events, which is the direction of pragnanz, which is a balanced state, a good gestalt. Good Gestalt includes the properties of order, simplicity, stability, symmetry and so on.

The field of observation that becomes everything faced by an individual has a dynamic nature that is likely to lead to the pragnanz state, which is a balanced state. Problematic state are conditions that are not pragnanz, irregular, not simple, unstable, asymmetrical and so on and the problem solving is to make changes in the structure of the field or that by including things that can bring things that are 
problematic to the nature of pragnanz. Meanwhile, the four main laws are additional principles that strengthen or assist the process of becoming the pragnanz. In solving problems we regulate the problems we face according to the principles contained in the four laws as well. These four laws are closeness, closure, equality and continuity (Suryabrata Sumadi, 1990: 297).

\section{State Defense Concept}

Benny Suryo Septanto (2019) explained that state defense is a concept that was compiled in a state legislation on patriotism of all components of a country in the interests of maintaining the existence of the country. Physically this can be interpreted as a defense effort against physical attacks or aggression from those who threaten the existence of the country. Non-physically, the concept of state defense is defined as an effort to play an active role to advance the nation and state; both through education, morals, social and welfare improvement for all components of the nation.

In strengthening the state defense, the Indonesian government also formed the concept of state defense based on the 1945 Constitution article 27 paragraph (3) which states that "Each citizen shall have the right and duty to participate in the effort of defending the state" and in the 1945 Constitution article 30 paragraph (1) and (2) which states that "Every citizen shall have the right and duty to participate in the defense and security of the state" and "The defense and security of the state shall be conducted through the total people's defense and security system, with the Indonesian National Military (TNI) and the Indonesian National Police (POLRI) as the main force, and the people as the supporting force". This means that constitutionally the state defense binds all Indonesian people as the rights and obligations of every citizen without exception.

The rights and obligations of each citizen in state defense are more clearly stated in the applicable laws and regulations such as Law No. 3 of 2002 concerning National Defense in article 9 paragraph (1), shows that the definition of state defense efforts is:

"The attitude and behavior of citizens imbued with their love for the unitary state of the Republic of Indonesia based on the Pancasila and the 1945 Constitution in ensuring the survival of the nation and state. The effort to defend the country, apart from being a basic human obligation, is also an honor for every state that is carried out with full awareness, responsibility and willingness to sacrifice in the service of the country and nation."

Thus the state defense is divided into basic values of state defense, namely: (1) Love of the motherland, (2) Consciousness of the nation and state, (3) Belief of Pancasila as the state ideology, (4) Willing to sacrifice for the nation and state, (5) Has the initial ability to defend the country.

The assumption of state defense is the existence of a threat that endangers a country's sovereignty. Broadly speaking, there are three types of threats, namely: real threats, not-yet-real threats and mindset war threats. Real threats are threats that often occur and are faced at any time whether they come from within the country or from abroad, which are considered endangering state sovereignty, territorial 
integrity and the safety of the whole nation, while not-yet-real threats are threats in the form of open conflict or conventional war. The form is a war involving two countries involving each of the armed forces. Mindset or non-physical threats are threats caused by the development of information technology both regionally and globally that can threaten the existence of the Republic of Indonesia. This threat is massive, systematic and structured which continues to influence and undermines the thinking and identity of the Indonesian people through the influence of foreign ideologies that are incompatible with Indonesian culture.

\section{METHODOLOGY}

This research is a qualitative study often termed naturalistic research in the field of Sociology, ethnographic research in the field of Anthropology and case study research in the field of Psychology (Sutopo, 2001: 5-6). Neuman (2000: 65) mentions the existence of three perspectives in Social Sciences that will differentiate in research techniques, namely: Positivist, interpretive and critical. The quantitative approach is under the positivist perspective, while the qualitative approach is under the interpretive/constructivisic and critical perspective (Neuman, 2000: 65)

This research belongs to the constructivist social research category. This notion can be traced since the German Sociologist Max Weber (1864-1920) and the German philosopher Wilhem Dilthey (1833-1911). Dilthey distinguishes two basic types of science, namely: Naturwissenchachaft (based on abstract understanding) and Geisteswissenchaff (based on empathetic understanding). Whereas Weber argues that social science requires the study of the meaning of social action.

This perspective is associated with hermeneutics, which is a theory of meaning, which is found in literature (linguistics, literary criticism, art history). The emphasis is on studying texts which refers to conversations, written words or pictures. The goal is to find meaning that is inherent in the text. In addition, interpretive social science (ISS) is also associated with constructionism, ethnomethodology, cognitive, idealist, phenomenological, subjectivist, qualitative sociology and symbolic interaction (Ibid: 70-71).

In general, the constructivist perspective assumes that: (1) The purpose of research is to understand and describe the meaning of social action, (2) Social reality is not permanent made by human interaction, (3) Human nature is social which makes meaning and constantly understands its world, (4) Common sense as a strong theory in everyday life used by ordinary people, (5) Theory is a description of how groups of systems of meaning are raised and developed, (6) Explanation of true inherent in what is being learned, (7) Good evidence attached to the context of social interaction that is not fixed, and (8) Values lie in an integral part of social life, there are no false values, only differences in values (Ibid: 85).

Data collection techniques in this study used interviews and document analysis. The informants interviewed were students and lecturers of State Defense Campus and education experts. The analysis technique that will be used is crosssite analysis. In each case it will be carried out using an interactive analysis model. 
In this analysis model, three components of the analysis are: data reduction, data presentation and drawing conclusions on verification, carried out in an interactive form with the process of collecting data as a cyclical process (Sutopo, 2002).

In each case an interactive analysis was carried out. In data reduction activities, data selection, focusing, simplification, and data abstraction are carried out from the field notes. This process continues throughout the course of the study. In the data presentation, data processing is carried out and written in the description in the form of a narrative that is arranged logically and systematically so that it can draw conclusions from the research. In the process of drawing conclusions and verification, repetition, testing, tracking, matching data are carried out so that data that has high validity is produced.

\section{RESULTS AND DISCUSSION \\ Learning of State Defense Values at UPNVY}

National Development University "Veteran" of Yogyakarta (UPNVY) was first established as the "Veterans" National Development Academy (APN). The rationale for its establishment is: For an independent and sovereign nation the right to determine, regulate and plan its own destiny in accordance with the situation and conditions. One of the main objectives of the establishment of the Republic of Indonesia is to educate the nation's life. In connection with that goal, veterans of the Republic of Indonesia's independence fighters feel responsible and want to be involved in the education and teaching of their people.

National Development University "Veteran" of Yogyakarta (UPNVY) as state defense campus always trying to instill the values of state defense among students. The socialization and internalization efforts were carried out starting from incoming students through the activities of the Introduction to State Defense Campus Life (Pengenalan Kehidupan Kampus Bela Negara/PKKBN) for D-3 and S-1 students. In this activity there is a special public lecture session which is directly delivered by the Minister of Defense (Menham) with the theme "State Defense". The lecture was carried out in a small class consisting of 30 students for one day divided into two sessions. The material includes lectures, questions and answers, and group discussions to formulate the values of state defense for students.

Subsequent socialization and internalization efforts were carried out through a series of courses: Pancasila, Citizenship, Widya Mwat Yasa (Wimaya), Sports I and Sports II. The five courses have a content of state defense values for students in the present era. For example, instill a sense of responsibility, discipline, cooperation, tolerance, caring for the environment, the value of courtesy and so on.

Wimaya is the most important course in the state defense values. This course discusses and explains about Widya Mwat Yasa (Wimaya) which is an UPN education with the aim of students being able to understand, explain and implement the Vision, Mission, and Objectives of Wimaya Education courses. Wimaya is the formation of student character education to consciously learn to build the Indonesian nation, starting from building themselves to be capable of struggle and defending the country by increasing: (1) Identity by growing: ideal values that are 
believed, courage and wisdom, (2) Ethics by fostering religious honesty, understanding and spiritual intelligence and example, (3) Discipline, by fostering awareness of obedience, abiding by principles and managing time, (4) Creativity by growing: intelligence, thinking ahead (visionary/futuristic), discourse and realistic nature, and (5) Struggle, by fostering a sense of resilience (struggle), the ability to take the wisdom of the past from history, sincerity, responsibility and determination togetherness.

Normatively, the State Defense Campus label is easy to talk about. However, its implementation in the form of internalized values, the realization of the practice of values in life is still difficult to realize. Following are some of the opinions of students at UPNVY regarding the conditional state defense campuses.

According to Andito (a member of the Menwa), in general the meaning of state defense is to make every citizen abide by the 1945 Constitution and be aware of the Pancasila ideology in the midst of the rise of ideological issues. As a state defense campus, UPNVY has not yet seen the nuances of defending its country both among lecturers and students. The socialization efforts carried out through a series of Wimaya, Citizenship, Pancasila and Sports activities included. Comparing with other campuses there is no such thing as UPNVY. An example is the Sports course and the most distinctive nuance of defending the country is the Wimaya course. Through a series of activities it is hoped that UPNVY can motivate and inspire students. The obstacles are more for each student's own awareness. The problem is that in the context of state defense ideally there must be a strict Universitas Paturan. For example on the campus of the Universitas Pertahanan (Unhan) in Bogor which is also a state defense campus. The rules were made requiring students to participate in state defense training, while at UPNVY it was not required. This is an obstacle at UPNVY because it is not binding. Andito's suggestion to socialize and internalize the values of national defense for students must begin by disciplining the bureaucracy. Thus students can emulate it. Bureaucratic discipline within UPNVY is only part of it.

Bangkit's opinion which is also a member of the Menwa regarding UPNVY's state defense campus, according to him, there are two viewpoints of the state defense, namely for the scope of Indonesia and the scope of campus life. For the scope of the campus, it is clear that as a student is preferred to commit to college, carry out the obligations and duties as a student. Students also involve themselves in organizations that are available to develop themselves, for example Menwa, Mapala, Scouts and so on. Students must also be prepared if sent as volunteers in areas that experience disasters if needed. According to Bangkit, the nuances of defending the country have not yet been felt in the UPNVY campus environment both among lecturers and students. For example there is still an empty class with no information. Simply, there are lack of role models both among teachers and education staff, even in the bureaucracy there seems to be difficulty. According to Bangkit as a member of the Menwa, the introduction of the values of state defense was more on Menwa's education. In Menwa education, it is taught about the values of state defense separately, the problem is that there is a separate training from the MenWa and state defense is taught starting from the basic exercises. Members of 
the Menwa also received Military Basic Education (Pendidikan Dasar Militer/Diksarmil) which also had the values of state defense substance. Further education is the Leadership Puskader (Puskader Kepemimpinan), here is also instilled values of state defense. The slogan of discipline, struggle and creativity which is also an implementation of the value of defending the country as a whole has not yet been realized. For example, it is easy, after graduation activities, garbage is always scattered here and there. This means that there is no overall awareness.

The other opinion of students about the state defense campus was delivered by Vera, a 2017 Accounting Department student who is also a member of the English Language SAU (Student Activity Units). She knows UPNVY as a state defense campus after participating in the 2017 Introduction to State Defense Campus Life (PKKBN). According to her: “...State defense is not just a title and symbolic, not just wearing black and white clothes or military styles. But it can also be practiced .... I mean by being a good citizen is a state defense act. Because sometimes we ourselves still cannot obey small things such as traffic signs..."(Interview on July 23, 2019).

According to Vera, the nuances of state defense have not yet been felt in the UPNVY campus environment. "It is not yet from the individuals, there are still many of the students themselves who have not arrived on time, arguing there are consequences of 15 minutes, some are disciplined, and some are not. Also in front there is a signpost that we are in a green campus, but in fact there are still many who are smoking in front of the class. So instead of the individual themselves we still don't fulfill to these signs". (Interview on July 23, 2019). When asked about the service from the campus manager, Vera explained "... it's still lacking, the lack of it because there are miss information. For example information about Study Plan Form is still lacking in transparency and on Single Tuition Fee as well. Why do I get Single Tuition Fee at this rate? It hasn't been explained yet". (Interview on July 23, 2019).

Vera's suggestion to reinforce the state defense campus is to be even stricter with existing regulations. For example, there are already Monday-Tuesday rules for wearing black and white clothes, but there are still people who are wearing jeans. There is a gap on implementation of regulations between Campus 1 in Condong Catur and Campus 2 in Babarsari. On Campus 1 it tends to be tighter and on Campus 2 it tends to be more relaxed.

Meanwhile a student and member of the Student Executive Board named Aroma conveyed the importance of state defense so that we would love our own country more. We will come to know what role we must play for our own country. She gained understanding of defending the country the first time from campus and then added insight into her state defense through independent information search. She considered that the UPNVY campus as a state defense campus could not yet realize the value of state defense as a whole. This might be due to the lack of state defense course material. In the Wimaya Course, only the main points were conveyed, no provisions were given for tomorrow what kind of reality they were facing. In the Pancasila, Citizenship and Sports Course nuances of the state defense material are also lacking. This condition is complicated by the reality of the current 
generation which is more inclined to Western culture. Some student does not prefer talking about state defense like this and are considered a waste of time. This is a challenge for lecturers to develop the material and learning techniques.

According to Aroma, the slogan of struggle, discipline and creativity has yet to be seen in the nuances of UPNVY. To make it happen, it must start on oneself, starting with the making of rules and role models from the lecturers as a reference. According to her the obstacle at UPNVY is the difficult bureaucracy factor. Changing rules and rigid personality (saklek). However, whatever the circumstances, the value of defending the country makes UPNVY campus different from other campuses. UPNVY students are also different from other campus students (Interview on August 5, 2019).

Another opinion was conveyed by Oktaviani, a Informatics student class of 2017 who is also a member of Scouts SAU, in an interview conducted on August 2,2019 . According to her state defense is very important to defend this country and must be done by students. The hard-won independence must be maintained, lest any of the nation escape. Students as agents of change must be able to maintain and provide positive change.

She knew the UPNVY campus as a state defense campus from the beginning of entering college through PKKBN. The lecturers have already pointed out that the UPNVY campus is different from other campuses with the characteristics of a state defense campus. The most distinctive feature is Widya Mwat Yasa (Wimaya) and Sports Course that are not found on other campuses. Through sports we can take care of our body. As a good nation, we must be healthy. Through Wimaya we can find out the ins and outs of the UPNVY campus in relation to state defense. Why does the UPNVY campus become a national defense campus? Because the founders of this campus were veterans. Through Pancasila Course, we can know and understand our ideology and can defend. Do not let us divide easily. Through the Citizenship Education Course can be a filter of global issues that conflict with prevailing norms.

The slogan of discipline, struggle and creativity which are also the values of state defense cannot be optimally practiced in the UPNVY campus environment. To make it happen for students, UPNVY must have a program to encourage students to be able to use their free time to run organization. By participating in an organization we can get some skills that we cannot get in academia. For example leadership, good cooperation and so on can be valuable for the nation. For example, in Scouts SAU are taught a variety of useful soft skills. The obstacle, so far, students seem indifferent and do not care. Even though the practice of state defense for students is easy, such as participating in academic activities well, trying to be disciplined, valuntering and active in organizations, therefore better socialization is needed.

A lecturer of Pancasila Course in UPNVY said that the main obstacle in realizing the state defense campus was the people's mindset. How actually the leaders and officials must have the same perception first. This does not yet exist because of the weakening of the state ideology. We are actually already clear of the 
state ideology of the Pancasila, as a guide. This guidance is in the context of nation and state.

Secondly, we say that we defend the state, since its establishment UPNVY has defended the country. Why it has been defending the country? Historically the UPNVY was established after the revolutionary war against colonialism. The fighters came it's time to advance the people's education, which previously struggled to take up arms turned to fight in another form, namely in the field of education. Our present condition is trapped in the capitalist concept. Our ideology of Pancasila is only included in the imagination because in fact, it is not implemented. In the context of education, many people are only teaching but not educating. This has caused failure in the internalization of (state defense) values in the education process. As an alumni of UPNVY too, he also felt the spirit of the soul when he entered UPNVY, he already knew that UPNVY was a great campus. The nuance was lost after the reformation in 1998. The wind of openness and freedom exhaled by excessive reforms eliminated the value of discipline.

The phrase owned by UPNVY which reads "Discipline, struggle, and creativity" are the values of the state defense that will be even better if added the value of "honesty". Instead it can be "Honest, disciplined, struggling and creative", with 4 concepts of state defense at UPNVY, namely: willing to sacrifice for the sake of the nation and state, love the motherland, believe in Pancasila as an ideology or the basis of the state and have basic skills in state defense. Reality is happening, talking about loving the motherland but sometimes there are those who do not know the motherland; talk about Pancasila ideology but there are still those who are not sure.

Freedom which is interpreted as freely as this is, which then we only print uhmm or graduates of knowledgeable people, but sorry to quotes are not strong in mental or moral. The spirit of state defense, the spirit of struggle, is forgotten. For example, if I meet with a number of alumni abroad, yes there are also those who work in the foreign department. What happened? their spirits are gone. Sometimes they know that for example there are illegal Indonesian Foreign Workers, they are also Indonesian citizens that we must protect. These spirits have started to wear off. Well, because of what? because we have again not understood the realm of the ideological frame which name is Pancasila, which has begun to fade.

Another opinion was conveyed by lecturer of WimaMya Course and at the same time the Sports Course instructor, who was conveyed in an interview on July 23,2019 . According to him during his teachings he had reintroduced the values of state defense to students. In this process there are emphases about how students can later behave or in the term empathy for the state of the country, such as the emergence of a sense of nationalism.

The current generation of students has multidimensional crises so that they are indifferent to the conditions of the state so that the state defense material becomes importants. Motivation needs to be developed so that students grow love for the country and have the initial ability to defend the country. In the context of its capacity as a student, state defense does not have to take up arms which are the 
realm of the TNI/Polri, but can be done by maximizing achievements in accordance with their respective fields, preserving a supreme culture and so on.

The values of state defense can be harmonized and can be matched with the values of "Discipline, Struggle and Creativity", and with the "Widya Mwat Yasa". There is synchronization between phrase with the value of discipline, struggle and creativity of almost more than $50 \%$. These concepts are easily learned by cognition but difficult to practice. Implementation in UPNVY campus community has not reached 50\% either among students, education staffs and lecturers. Workshop, training or the like have not shown the expected results. For example there are lecturers who are still only concerned with the problem of transfer of knowledge but do not instill the values of struggle. Therefore all courses must be linked to state defense values. Only a few lecturers have done it. If the majority has already done so the behavior of students, education staffs and lecturers will also be structured according to the expected values. "... The spirit of state defense to serve ...".

UPNVY campus is trying to set an example for students by requiring training in state defense such as lecturers and education staff, but has not been able to change behavior. There is too much listening to lectures, plus the average participant is old because they have worked for decades. The activity seemed just a formality. After training the material enters the bag. Their contribution to behavioral change seems to be non-existent and has not yet met the goals.

His advice is that training is important, but in daily practice there must be firmness in leadership as a role model for those below. Evaluation must continue and courage to admonish wisely any deficiencies or violations. The lightest target of state defense is to change the mindset and behavior. Training materials must be well prepared, in consultation with experts in their fields.

Meanwhile UPNVY State Defense Campus, in an interview on August 26, 2019, stated that state defense starts from loving the motherland, being conscious of the nation, belief of Pancasila. This should be instilled from the start. The implementation in campus life grows values such as discipline and good performance. To realize this, it cannot be separated from our relationship to or to God Almighty. People who have good performance are usually also accompanied by good religious understanding as well. He began to instill this by always beginning and ending lectures by praying. If we pray, God will be with us. Knowledge comes not from humans but from Allah SWT. “... All activities must always remember God. Actually, life is just like that... ". He conveyed that even in the UPNVY environment, disciplinary issues were still not focused. Even though being disciplined means being united. United because strong and strong because united. Unity is Team Work.

Instilling the value of state defense must able to look back, how the history of national movements to achieve independence. Our predecessors have sacrificed a lot. This spirit of calling and sacrifice is to be emulated. Now we only have to inherit and fill that independence. We must be grateful for it, and fill it with good performance according to the field and capacity that we have. This is a state defense that needs to be internalized which in the context of students is "... Willing to sacrifice to learn." This relevance is socialized in Wimaya Course. 
The socialization and internalization of the values of state defense must go through an ongoing habatuisi process. A process like this will result in a disciplined attitude. State defense in this sense is obeying the rules or laws. The habituisi requires an exemplary that does not only depend on one figure. This is included in creating an atmosphere of state defense, so that when outsiders enter the environment, UPNVY immediately feels a touch of state defense.

\section{Model of Socialization and Internalization of State Defense Values for UPNVY Students}

The learning process is a unique process, a transfer of knowledge that involves elements of cognition (awareness), affection (feeling) and conation (behavior). The three components are expected to change to a more perfect direction after going through a series of learning processes. Therefore various methods, techniques and learning methods are formulated to achieve maximum results.

UPNVY campus which bears the title of state defense campus continues to formulate the best learning methods to socialize and internalize the values of state defense for students. The hope is that the state defense campus is not only an empty slogan, but it animates every UPNVY graduates. The learning process that has been done is not only transfers knowledge, but also transfers values (state defense) that are internalized and becomes the spirit.

Prof. Dr. Anik Ghufron, a learning technology expert at Yogyakarta State University, in an interview on August 7, 2019 explained that the factors that influence success in learning. For example, first, the model or method of learning does not match with the type of learning activity desired. This happens because when the lecturer wants to use a certain learning method, then the method chosen is the method that they have. They do not want to use learning methods that are appropriate to the learning activities of the students. Student learning activities can be divided into 3 (three), namely motoric activities, activities related to theoretical studies and activities related to the appreciation of values. This must be considered in choosing a learning method that touches.

Second, the failure of the learning process can be caused by unclear learning outcomes (LO) as part of the learning product. For example, if it is more related to application practice, the LO must use verbs. This is often ignored so that there is no synchronization between lectures and learning activities. "...Kuliah ya kuliah, belajar ya belajar".

Third, there is no monitoring of the progress report, for the learning event ideally from one learning phase to the next there is monitoring. If there is already a monitoring, then if there is a deviation, it will be found out where the error lies.

But basically, all circumstances can be changed through the learning process. We must not say that a child (student) is incapable, stupid, can't understand the material and so on that has a negative connotation. All can be conditioned and the environment must be arranged to support learning. According to behavioristic thinking everything can be reached, regardless of whether in the age of children and adults even the final limit is death. 
But the conditionals are also different. There is a saying that says "Inviting or changing smart people will be more difficult than inviting people who are right". There are also times when the student's character is to rebel. Rebel in the sense that they are already have their own ideas. Now what needs to be done is to try to engineer the mindset to be the one we expect (brain-storming). Through this process expectations will be converted into student needs. For example, the Yogyakarta State University (UNY) campus now, with its slogan "Leading Character Education" seeks to create supporting behavioral characteristics, actions and thoughts. Values and moral standards are standardized.

According to Prof. Anik Gufron, for the UPNVY case, State Defense Campus must become the central initiation of the socialization and internalization of the state defense values. Five courses that are agents of state defense values (Wimaya, Pancasila, Citizenship, Religion and Sports) have not been sufficient. The values of state defense must be integrated with all lecturers or all courses. The five courses are central to the movement (the toll road). But do not be charged on the five courses. State defense must exist in the curricular, extra-curricular and in everyday life.

Meanwhile, a lecturer of the Wimaya and Sports courses, in an interview on July 23, 2019, submitted suggestions for realizing UPNVY as a state defense campus by improving the state defense materials contained in the Wimaya course to be more expanded because currently the state defense materials are only a little and lecturers must be guided by the book. Even if the lecturer improvises, it only applies to the class being taught (inequality occurs). Ideally the material is updated every year or two so that the material does not saturate. Ideally, this should be accommodated as a form of coordination, but the conditions on UPNVY's state defense campus are not yet optimal. As a state defense campus, it should accommodate an agent of state defense values, namely Wimaya course as a means of coordination and synchronization of lecture material.

Even so, he tried to structure the lecture material so that the maximum learning outcomes (LO) achieved. In sports, there is more emphasis on the values of discipline, responsibility then cooperation, which in sports are discipline, responsibility, cooperation and loyalty. Suppose they have exercises in a team, then about how they are loyal to friends or groups. In the Sports Course physical conditions and mental conditions are also developed.

UPNVY State Defense Campus also conveyed the same thing, namely the importance of coordination with all lines to realize the UPNVY state defense campus. The thing that often happens is the throwing of responsibilities, even though its responsibilities of all parties. Not only the responsibility of the State Defense Campus. To realize the ideal obsession of the state defense campus must begin with good cooperation and start by realizing (1) Discipline and (2) Evaluation 


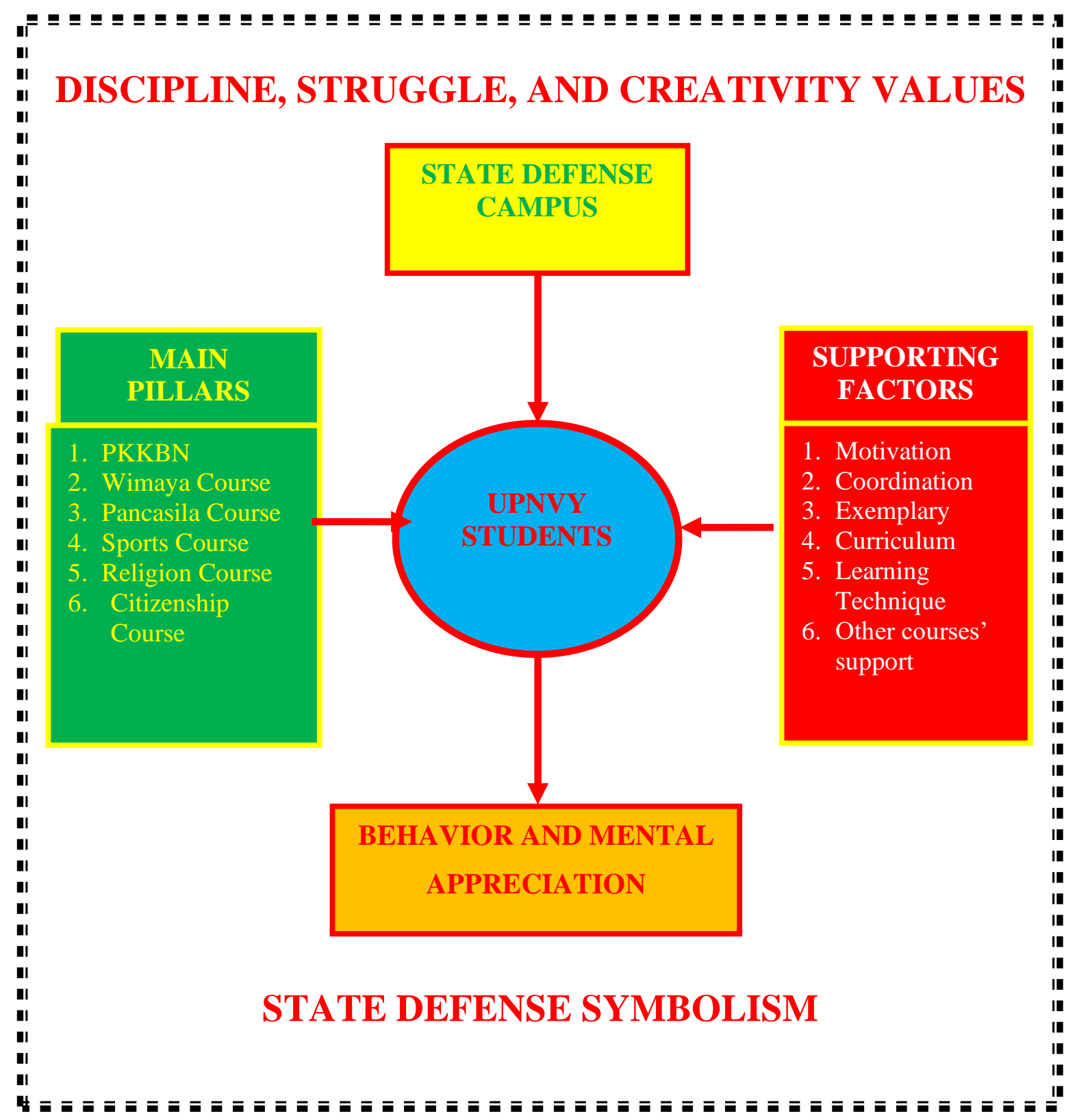

The model above explains that the first thing to do is to unify perceptions about state defense in campus life under the coordination of the State Defense Campus. Concepts, behavioral indicators, achievement indicators (change) and 
evaluations need to be formulated. This is a guide for the entire UPNVY campus community.

The introduction of state defense values begins when UPNVY students first enter the university, the values of state defense introduced through the Introduction to State Defense Campus Life (PKKBN). The next introduction was carried out through five courses in the pillars of state defense namely Widya Mwat Yasa, Pancasila, Citizenship, Sports and Religion. The lecturers must always coordinate the material, learning techniques, material actualization and evaluation.

The socialization of state defense values at UPNVY should not only be borne by the five courses above, but must be supported by all existing courses. Therefore all courses must be linked to the value of state defense. All fields of science studies at UPNVY must be able to find their touch points with the value of defending the country. Therefore it is necessary to arrange a curriculum that is unique to UPNVY. All courses must have learning outcomes (LO) that touch the value of state defense.

The atmosphere of state defense must be strong in the UPNVY campus environment. The value of struggle, discipline and creativity must be real, therefore exemplary is needed. Exemplary is from all teaching staff and education staff. Indicators that are often assessed are academic services, bureaucracy and time discipline. The atmosphere will be felt with the presence of the symbolization of the values of the country's defense such as the names of heroes, songs of struggle and so on.

\section{Discussion}

Humans are dynamic social creatures. Knowledge, thoughts and actions can change due to communication and interaction with the environment. Behavioristic views assess everything that exists in humans can change without recognizing age restrictions. This is the hope for every design that wants a change in human attitudes and behavior.

The socialization and internalization of values is the appreciation process carried out by the communication process. The success of communication depends on the transactional process between the elements of communication, namely: communicators, messages, recipients and the expected impact (feedback). Communication is also contextual that depends on the specific circumstances and conditions for the occurrence of the communication process. The effectiveness of communication is the integration of equal intensity of all components of communication.

The process of socializing and internalizing the values of state defense for UPNVY students required a process of communication integration as well. The main pillar of the lecturer as a communicator must have adequate capacity and capability. Mastery of the material (messages) and learning techniques (communication style) is absolutely necessary. This is required in a standardized standard for all course subjects. 
The values of state defense as a communication message must have strict limits. Concepts, moral standards and examples of defensive behavior must be standardized so that all communicators refer to the same message material. Then the delivery technique must also look at the contextual communicant (student) and the expected learning outcomes. Besides that it must still be supported by the motivation and enthusiasm of the communicant (students) in the communication process. This is the communicator's challenge in producing messages, delivering messages and creating an atmosphere of communication.

The process of socializing and internalizing the values of state defense on the UPNVY campus has not been well integrated. It needs refinements and improvements in aspects of communication that include communicators, messages, recipients and expected effects. Therefore this study has recommended a model that emphasizes communication, integration, coordination, standardization and evaluation.

\section{CONCLUSION}

a. The model of socialization and internalization of the values of state defense for UPNVY students is carried out through an integrated process under the coordination of State Defense Campus. The process is carried out since the student enters until the student completes studies. Five courses in the pillars of state defense (Wimaya, Pancasila, Citizenship, Religion and Sport) and all courses provide content for state defense. The process is strengthened by example in discipline, struggle and creativity. The symbols of state defense are also presented to create an atmosphere of state defense.

b. Supporting factors to realize UPNVY as a state defense campus is a historical factor, that UPNVY was established to facilitate the national movement fighters in the independence period to study. The spirit of the struggle to defend the country continues to be maintained and become a maintained value.

\section{BIODATA}

Isbandi Sutrisno, S.Sos, M.Si is a lecturer of Communication Science Dept, UPN "Veteran" Yogyakarta, Yogyakarta, Indonesia. He has a research interest in Advertising and Traditional Cultural.

Sigit Tripambudi S.Sos., M.Si is a lecturer of Communication Science Dept on UPN "Veteran" Yogyakarta, Yogyakarta, Indonesia. He has a research interest in intercultural communication, Advertising and Cultural Studies

\section{REFERENCES}

\section{Book}

Denzin, Norman K dan Lincoln, Yvonna. 1994. Handbook of Qualitative Research. 
London : Sage Publications

Feis, Jess, Feis, Gregory J, 2008, Theories of Personality, Terjemahan, Yogyakarta, Pustaka Pelajar.

Littlejohn, Stephen W. 1999. Theories of Human Communication. sixth edition. California : Wadsworth Publishing Company.

Neuman, W Lawrence. 2000. Social Research Methods : Qualitative and Quantitative Approaches. fourth edition. Boston : Allyn and Bacon.

Snyder, CR, J Lopez, Shane ,2007, Positive Psychology: The Scientific and PracticalExploration of Human Srengths, California, Sage Publication

Suryabrata, Sumadi, 1990, Psikologi Pendidikan, Jakarta, CV Rajawali

Suroto, Agus, 2015, Buku Bela Negara Dan Widya Mwat Yasa Edisi ke-3 (Edisi Revisi).

Sutopo, HB. 2002. Metode Penelitian Kualitatif. Surakarta: UNS PRESS.

\section{Paper}

Ryamizard Ryacudu, Pembekalan Mentri Pertahanan pada Mahasiswa Baru Universitas Pembangunan Nasional "Veteran” Yogyakarta, Agust 13, 2019.

Suryo Septanto, Bennyta, Mencetak Mahasiswa Berkarakter Bela Negara Menghadapi Revolusi Industri 4.0, LP2M Universitas Pertahanan, Bogor, Agustus 19, 2019. 